\title{
Estimating regional exports of services trade for the UK
}

Keith Brook and Kelly Taylor

Economic and Policy Analysis, Department for Business, Innovation and Skills (BIS)

\section{SUMMARY}

The Department for Business, Innovation and Skills (BIS) undertakes an annual analysis of regional exports of services. Coverage is limited to about 30 per cent of the value of the UK's exports of services and includes Communication, Computer and information and parts of Royalties and license fees and Other business services. This paper describes the methodology used, the available results and the limitations of the analysis.

\section{Introduction}

In 2009, total UK exports of services were $£ 159$ billion at current prices, down from a peak of $£ 171$ billion in 2008. Between 2000 and 2008 UK exports of services more than doubled while exports of goods increased by only about 30 per cent over the same period. In recent years, the UK has consistently recorded the second highest level of exports of services in the world, following the USA.

Figure 1 shows the breakdown of UK exports of services using product groupings consistent with those defined in the IMF Balance of Payments and International Investment Position Manual (BPM6). Data are collated from a number of different sources and published by the Office for National Statistics (ONS). Major sources include:

- Transportation - Civil Aviation Authority and Chamber of Shipping

- Travel - ONS International Passenger survey

- Insurance and finance - Lloyds and other insurance companies, Bank of England, Security dealers

- Communication, Construction, Computers and information, Royalties and licence fees and Other business services - ONS International Trade in Services survey (ITIS) 


\section{Figure 1 Exports of services by product, 2009}

$£$ billions

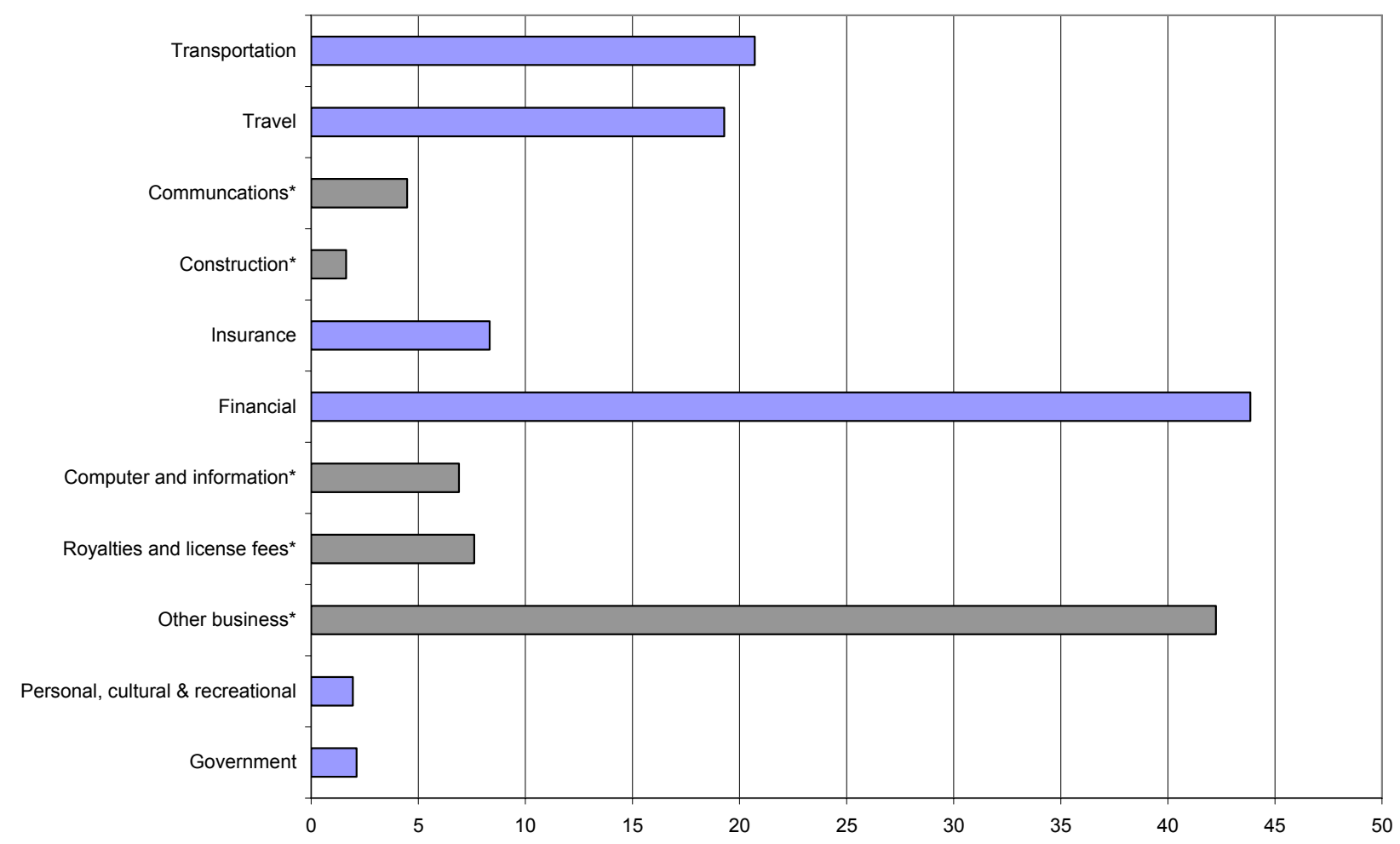

Source: ONS Pink Book 2010

Note

* The categories in grey are regionalised

The regional analysis is limited to data collected from the ITIS survey covering Communication, Construction, Computers and information, Royalties and licence fees and the majority (about 75 per cent) of Other business services. These account for about 30 per cent of total UK exports of services. From 2009 reference year, a separate Film and Television survey has been merged into the ITIS survey and from next year this will give a small increase in the coverage of Royalties and licence fees in the regional analysis.

Data for Transportation, Travel, Insurance and Finance are not available in a suitable format which allows a regional allocation to be undertaken. For these services allocation to a region may be less meaningful since the geographic location of the sales transaction and of the service activity may differ.

\section{International Trade in Services (ITIS) survey}

The ITIS survey records the value of both exports and imports for 51 different services products. A number of products are combined together to give a particular BPM category. For example the 
Business management and management consulting category in the Pink Book (Table 3.9) comprises seven separate ITIS products.

ITIS is a survey of about 19,000 businesses which are stratified by industry covering mainly the production, distribution, business and other services in the market sector. The sample is split between a panel of known traders and a random sample of 'high propensity' companies from Standard Industrial Classification (SIC) industries which are known to have significant levels of services trade. This includes computer services, research and development and other business services (UK SIC 72-74).

The ONS Annual Business Inquiry ( $\mathrm{ABI}$ ) includes a question which asks businesses if they trade in services and the value of any trade. This $A B I$ filter question is used to identify businesses which routinely trade in services and are included in a panel of about 7,000 companies which are queried each year. The largest traders (about 700 companies) are required to give a quarterly return to allow quarterly trade in services data to be estimated for National Accounts purposes.

In past years the ITIS survey also sampled about 4,000 businesses which were outside of the high propensity industries. The majority of these companies gave a nil return and in total accounted for only about 2-3 per cent of the total ITIS value for exports. From 2007, this part of the sample has been dropped and replaced by $A B I$ returns which are not included in the ITIS panel or covered by the 'high propensity' industries. The ABI does not collect product and partner country details and these are imputed. Table 1 gives a summary of the ITIS sample and the contribution of each component to the total ITIS export value. In 2008, the ABI component accounted for about 3 per cent of total ITIS exports.

\section{Table $1 \quad$ Sample structure of IT IS survey, 2008}

\begin{tabular}{lcc}
\hline & Number & $\begin{array}{c}\text { Approximate share of ITIS } \\
\text { export value }\end{array}$ \\
\hline Known traders & 674 & $58 \%$ \\
Quarterly panel & 6,455 & $29 \%$ \\
Annual panel & & \\
Weighted sample from IDBR & & $10 \%$ \\
High propensity industries & 7,660 & $3 \%$ \\
ABI & 4,481 & $100 \%$ \\
\hline Total Sample & & \\
\hline
\end{tabular}

Source: ONS International Trade in Services (ITIS) survey 


\section{Coverage and regional allocation}

Out of 51 ITIS products, 37 are included in the regional exports analysis comprising about 80 per cent of collected ITIS export value. This corresponds to about 30 per cent of total UK exports of services. ITIS products are only regionalised where the ITIS data is the source of all or nearly all of the corresponding Pink Book category.

For some categories, data from other sources are added to the ITIS data to obtain the Pink Book total. For example ITIS data only accounts for about 20 per cent of Other miscellaneous business services published in Table 3.9 of the Pink Book. Such data are excluded from the Regional analysis. The other major exclusion is Insurance and auxiliary financial services, where ITIS accounts for only about 25 per cent of total UK exports of insurance and financial services.

The regional allocation is undertaken at the NUTS1 geographic level. These comprise nine English regions plus the devolved administrations of Scotland, Wales and Northern Ireland which are combined together.

The ITIS survey does not collect the geographic location of the transaction, partly due to the need to minimise response burden on companies. It is also likely that if collected, the quality of the geographic location would be low. The geographic location of the transactions are modelled by linking the ITIS data back into the Inter-Departmental Business Register (IDBR) from which the detailed company structure can be determined.

The ITIS survey collects and reports transactions at a company reporting unit (RU) level. Each RU may comprise one or more local units (LU) across which a number of different or similar business activities may take place. Where a company has more than one LU, these may be located in the same or across different regions. The IDBR includes an employment measure for each LU and this is used to apportion the export value of each product within a company to its local units.

As noted, ITIS products are grouped into corresponding Pink Book categories. Pink Book data differ from ITIS totals due to adjustments which are made as part of the National Accounts balancing process. The published regional export data are adjusted to be consistent with the published Pink book data and so take account of the balancing adjustments. As noted, the regional allocation is limited to Pink Book categories where ITIS is primarily the only source of data.

Data for each product and region are disclosure checked to ensure that there are more than three companies and that a company with the largest component cannot be identified if it dominates other companies in the cell. The cell is considered to be non-disclosive if:

$\mathrm{T}-\mathrm{M}-\mathrm{N}>0.1 \mathrm{M}$

where $\mathrm{T}$ is the total export value in the cell, $\mathrm{M}$ the value of the company with the largest transaction and $\mathrm{N}$ the value of the company with the second largest transaction. 
No regional totals are included in the published tables because coverage is only partial and comprises groups of products which do not make a meaningful aggregate in terms of BPM definitions. This helps to reduce the risk that the published data is considered to be representative of the regional picture for all service products.

\section{Apportioning trade to the regions using LU employment}

Where the RU comprises more than one LU the reported trade in service may occur at one or more of the LUs, which may be in a number of different regions and more than likely includes the $\mathrm{RU}$ region. In the absence of any specific geographic knowledge of where the actual export transaction is taking place, apportioning the export value to each of the company's LUs is considered to be the best available compromise when the company has only a few LUs.

However, this approach is considered to be questionable where the company has a large number of LUs since it is unlikely that all of the sites will be actively involved in the specialised activity associated with export of services. Companies with a high number of LUs are often in the Communication or Distribution sectors and the LUs are retail outlets. In such cases allocating the transaction to the RU, which may be the location of the company headquarters, is considered to be the best compromise.

A choice needs to be made on a threshold for the maximum number of LUs in a company, when this allocation change is made. The share of export value in relation to the number of local units and regions is shown in Figure 2. In 2008, 43 per cent of the export value was reported by companies with only $1 \mathrm{LU}$ with a further 10 per cent accounted by companies with 2 or more LUs, where all of the LUs are in the same region. Hence, 53 per cent of the total export value was derived from companies where the region is correctly allocated because all of the LUs are in one region.

A further 19 per cent of the export value is accounted for by companies which have between 2 and 4 LUs, and as shown in Table 2, the majority of these companies have LUs in only 2 regions. In this case apportioning the export value to each LU is considered to be the best approach since one or more of the LUs may be the exporter.

However, as the number of LUs increases the likelihood that all of the LUs are involved in services export activity reduces and more than likely it will be concentrated either in the RU or selected LUs. Figure 2 shows that 11 per cent of the export value is accounted for by companies with 20 or more LUs with Table 2 showing that more than two-thirds of the value is from companies with LUs being present in all 10 regions. With 10-19 LUs the export value is 9 per cent of the total and Table 2 shows that no regional total dominates. 
Figure 2 Share of ITIS export value (\%) for different company LU structures and number of regions with a LU presence, 2008

Number of local units and regions

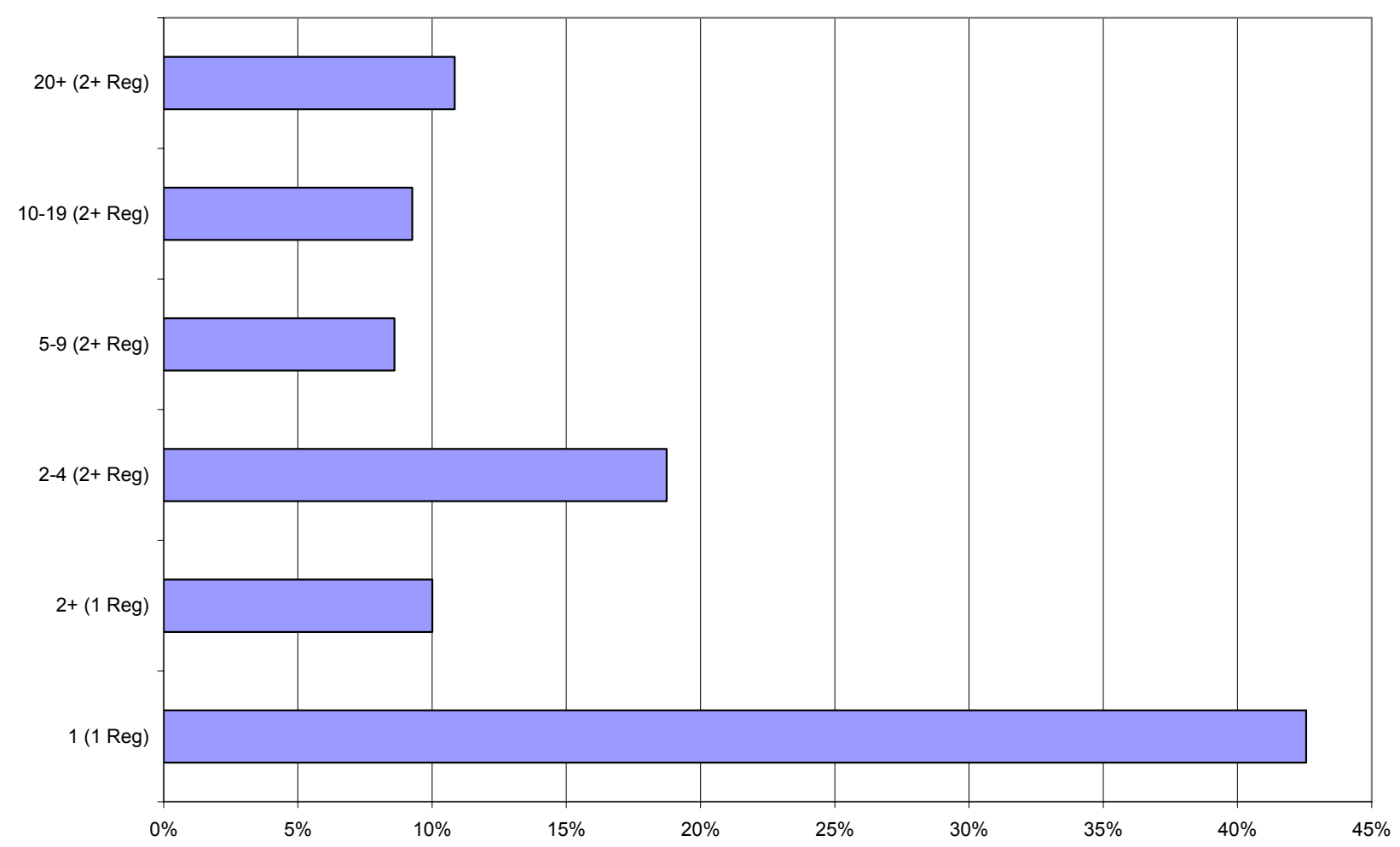

Source: BIS analysis of the ONS International Trade in Services (ITIS) survey

\section{Table 2 Share of ITIS export value for different company LU structure and number of regions with a LU presence, 2008}

Percentages

\begin{tabular}{|c|c|c|c|c|c|c|c|c|c|c|c|c|}
\hline \multirow{2}{*}{$\begin{array}{l}\text { Number of } \\
\text { Local Units }\end{array}$} & \multicolumn{11}{|c|}{ Number of Regions with a Local Unit presence } & \multirow[b]{2}{*}{ Total } \\
\hline & 1 & $2+$ & 2 & 3 & 4 & 5 & 6 & 7 & 8 & 9 & 10 & \\
\hline 1 & $43 \%$ & & & & & & & & & & & $43 \%$ \\
\hline $2-4$ & $7 \%$ & $19 \%$ & $15 \%$ & $3 \%$ & $1 \%$ & & & & & & & $26 \%$ \\
\hline $5-9$ & $2 \%$ & $9 \%$ & $1 \%$ & $2 \%$ & $3 \%$ & $2 \%$ & $0 \%$ & $0 \%$ & $0 \%$ & $0 \%$ & & $10 \%$ \\
\hline $10-19$ & $0 \%$ & $9 \%$ & $0 \%$ & $1 \%$ & $1 \%$ & $2 \%$ & $1 \%$ & $1 \%$ & $1 \%$ & $2 \%$ & $0 \%$ & $10 \%$ \\
\hline $20+$ & $1 \%$ & $11 \%$ & $2 \%$ & $0 \%$ & $0 \%$ & $0 \%$ & $0 \%$ & $0 \%$ & $0 \%$ & $1 \%$ & $8 \%$ & $11 \%$ \\
\hline Total & $53 \%$ & $47 \%$ & $17 \%$ & $7 \%$ & $5 \%$ & $4 \%$ & $2 \%$ & $1 \%$ & $1 \%$ & $3 \%$ & $8 \%$ & $100 \%$ \\
\hline
\end{tabular}

Source: BIS analysis of the ONS International Trade in Services (ITIS) survey 
As noted, companies with a large number of LUs are typically in the retail or communication sector and it is considered that the export activity will more than likely be undertaken by the headquarters, probably the RU, or at most one or two LUs. Apportioning the service exports to all LUs is not considered to be meaningful in such cases and these are allocated to the region of the RU.

The remaining LU group 5-9 accounts for 9 per cent of the services export value with the majority of the value shared by companies with a presence in typically 3,4 or 5 regions. For this group there is some uncertainty as to whether it is more appropriate to allocate to the RU or apportion to each LU. Figures $\mathbf{3} \mathbf{a}$ and $\mathbf{3} \mathbf{b}$ show the regional allocation for two scenarios with a threshold of 10 or 5 LUs, together with apportioning all exports to all of the LUs or to the RU. These last two cases represent bounds in the allocation method.

\section{Figure $3 a$ Effect of different LU allocation methods on share of regional export of services}

Percentages

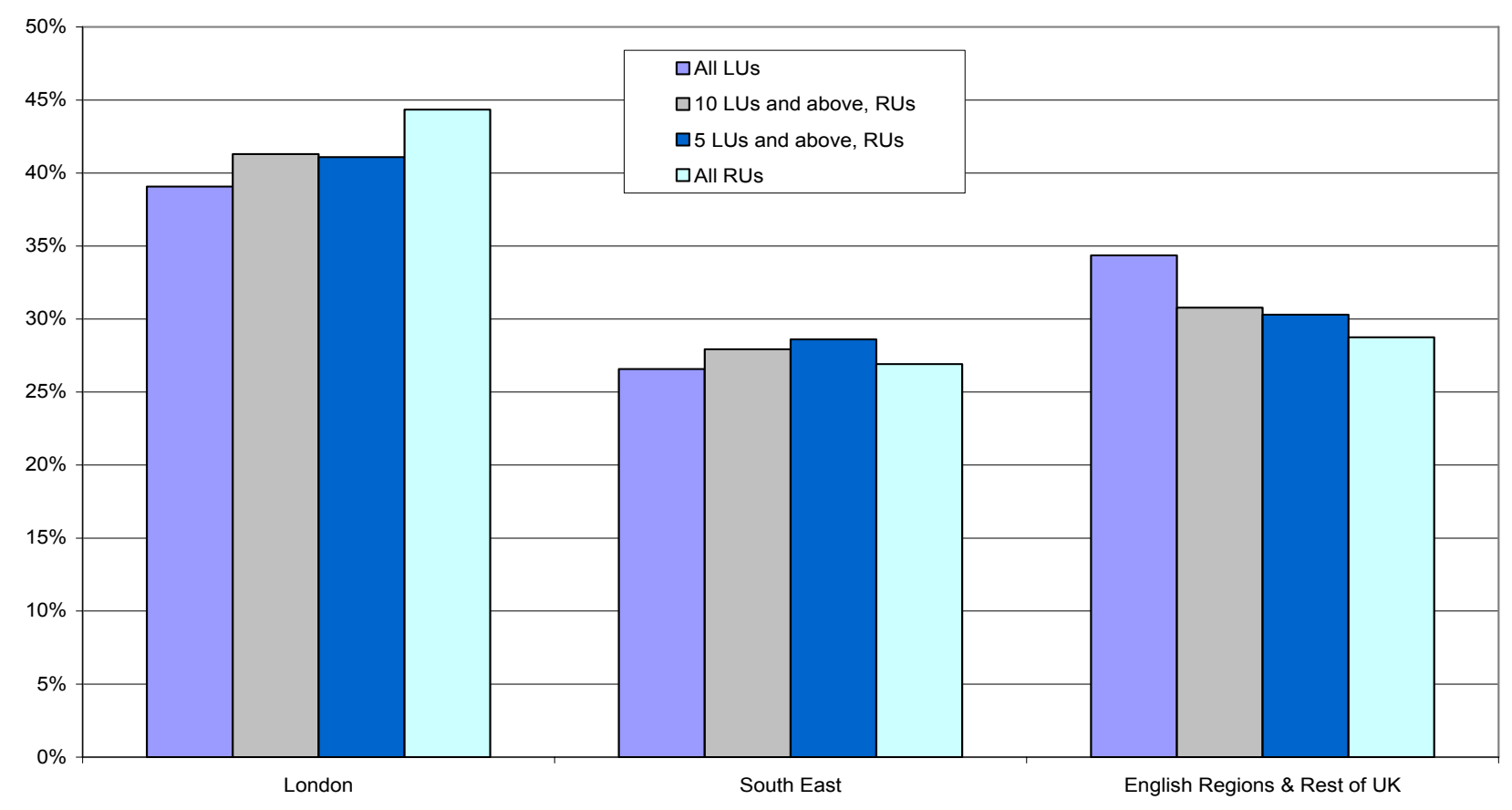

Source: BIS analysis of the ONS International Trade in Services (ITIS) survey

Figure 3a shows that the allocation to London increases as more of the value is allocated to the $\mathrm{RUs}$, which is to be expected due to the high presence of company headquarters in London. The converse is true for the English regions and the Rest of the UK which is again consistent with fewer headquarters being in these areas. The trend for the South East differs in that the RU and LU shares are the same with the other cases being higher. This is possible due to the interplay of the effects of apportioning to the LUs and/or the RUs and their geographic location in the four different scenarios. Figure $3 b$ shows similar trends for the regions excluding London and the South East, with the pattern for the East being similar to London and most of the remaining regions being similar to the English regions and the Rest of the UK group shown in Figure 3a. 


\section{Figure 3b Effect of different LU allocation methods on share of regional export of services, 2008}

Percentages

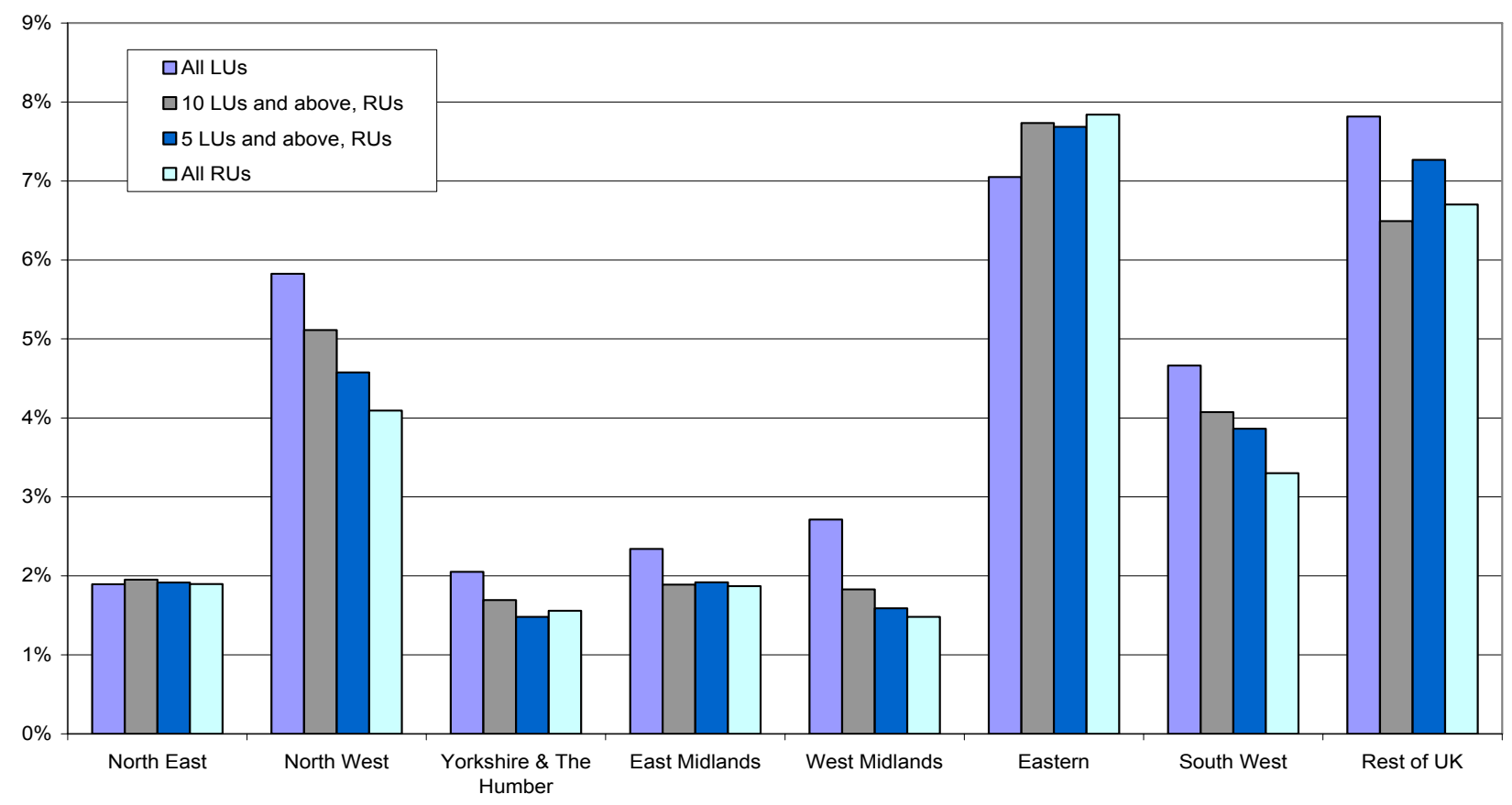

Source: BIS analysis of the ONS International Trade in Services (ITIS) survey

Figures $3 a$ and $3 b$ show that when using a threshold of 10 or 5 for the number of LUs, there is little difference in the share of the allocation for most of the regions. This is to be expected since, as shown in Figure 2, companies with between 5-9 LUs only account for 9 per cent of the total export value. The different allocation methods may have a greater impact at the product level as shown in Figure 4 for Computer and information services. However, for most regions the greatest change arises from moving from allocating all of the data to the LUs, to allocating to the RU where there are more than 10 LUs. Generally, the differences are smaller between using a threshold of 10 or 5 . Taking all of these considerations into account it has been decided to fix the threshold at 10 and apportion to the LUs using LU employment where there are fewer than 10 LUs and to allocate all of the value to the RU where there are 10 or more LUs.

In 1999, the former Department for Trade and Industry (DTI) funded a one-off voluntary supplement to the ONS ITIS survey to investigate the regional pattern of services exports. For one quarter some panel members were supplied with a list of their local units and addresses from the IDBR and asked to identify which of these local units undertook the reported exports of services. No additional product or value details were collected for the LUs. Returns were received for 74 companies which had 2 or more local units located in different regions. 
Figure $4 \quad$ Effect of different LU allocation methods on share of regional export of computer and information services, 2008

Percentages

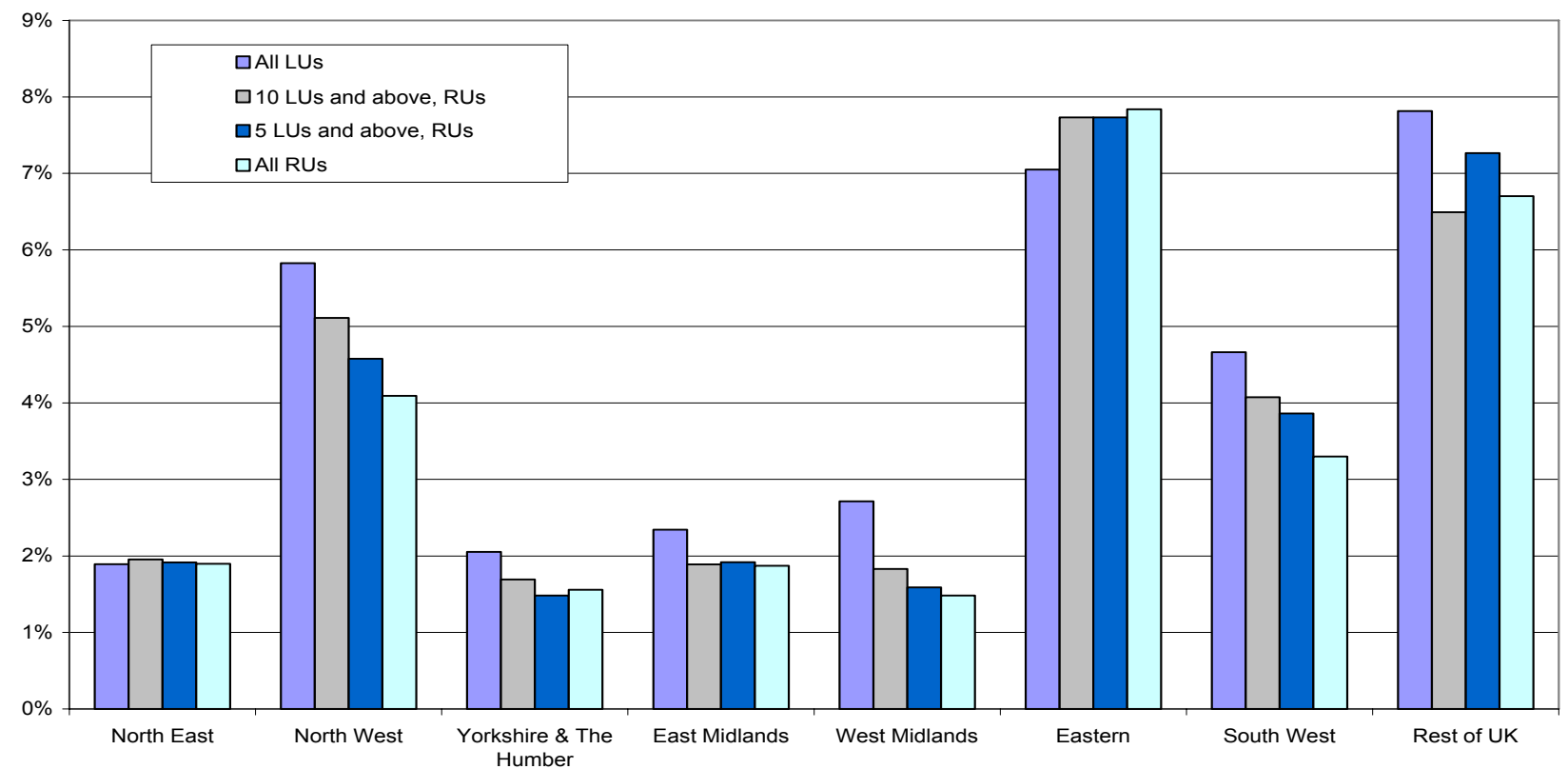

Source: BIS analysis of ONS International Trade in Services (ITIS) survey

Figure 5 Comparison of actual and BIS allocation methods, $1999^{1}$

$£$ thousands

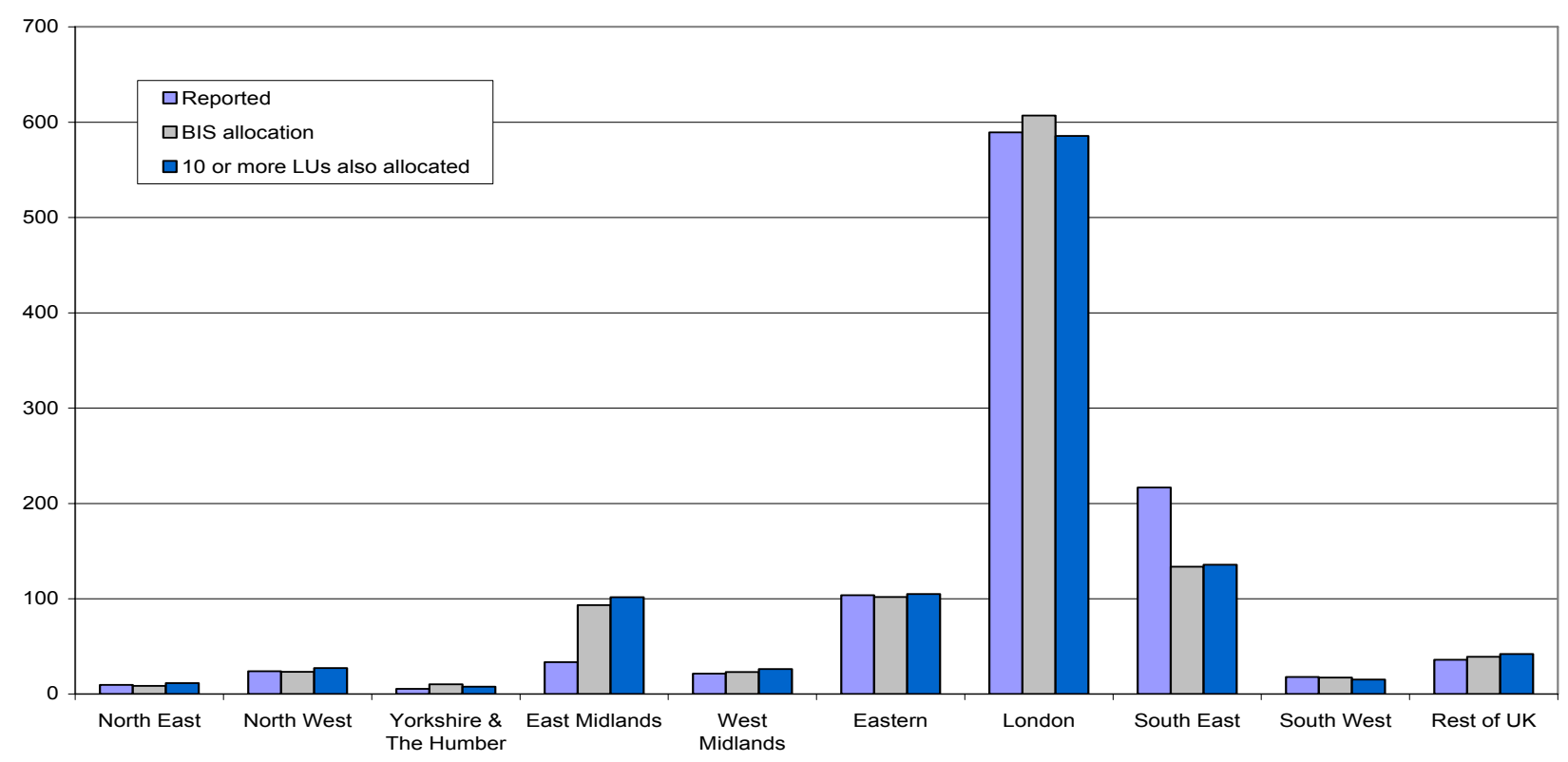

Source: Supplementary survey to identify exporting local units (LU) in ITIS sample, 1999

Note

1 Based on 74 returns 
For these companies, Figure $\mathbf{5}$ shows the reported regional allocation compared with that based on the allocation used in the BIS analysis. Considering the low number of returns, it is considered that there is reasonable agreement between the reported values and the BIS allocation method. Only 10 of the companies had 10 or more LUs which in the BIS method are now allocated to the reporting unit. Figure 5 also shows the impact of allocating these exports to each LU using the employment. The impact is minimal, although this cannot be construed that allocating to the $R U$ is necessarily correct.

\section{Results for regional exports of services analysis}

Tables 3 and 4 show for each service product that has been regionalised, the 2008 value and share as a percentage of its total UK service exports. The data can be used to show the relative size of exports between regions for a particular product or between products within a region. The analysis covers about 30 per cent of UK exports of services.

There can be considerable variability between years for a particular product and region. This can be due to changing patterns in exports of services, where individual companies obtain new or end existing export contracts. It may also reflect the level of reliability of the data, partly due to use of a sample survey for an activity that is not normally distributed across companies and partly due to the apportionment method.

Table 4 shows that exports of services are dominated by London and the South East regions. This is shown on a map of the UK regions in Map 1 for the aggregated value of the service products that have been regionalised. In 2008 London and the South East exported 42 and 27 per cent of the share with the East, North West and Rest of the UK having a share of 8,5 and 6 per cent respectively. The remaining regions exported less than 5 per cent of the share.

While short term annual variations may be somewhat volatile, it is possible that longer term comparisons will be more reliable. Between 2001 and 2006 the share in London, South East and East have decreased by 6,3 and 2 percentage points respectively with most of the other regions increasing their share by between 1 and 3 percentage points. This gives some evidence that the gap is decreasing across the regions.

In order to assess whether this trend is still valid when differences in population are taken into account, Figure 6 shows the regionalised service export value per economically active adult, indexed to UK=100 for each year. Over the five year period between 2001 and 2006 the index in London, South East and East has decreased by 40, 20 and 15 index points respectively with most of the other regions increasing by between 15 and 25 index points. 


\section{Table3 Regional value ${ }^{1}$ of exports of selected services, 2008}

$£$ millions in current prices

\begin{tabular}{|c|c|c|c|c|c|c|c|c|c|c|c|}
\hline \multicolumn{12}{|c|}{ Government Office Region (GOR) } \\
\hline Service & $\begin{array}{l}\text { North } \\
\text { East }\end{array}$ & $\begin{array}{l}\text { North } \\
\text { West }\end{array}$ & $\begin{array}{l}\text { Yorkshire } \\
\text { \& Humber }\end{array}$ & $\begin{array}{c}\text { East } \\
\text { Midlands }\end{array}$ & $\begin{array}{l}\text { West } \\
\text { Midlands }\end{array}$ & Eastern & London & $\begin{array}{l}\text { South } \\
\text { East }\end{array}$ & $\begin{array}{l}\text { South } \\
\text { West }\end{array}$ & $\begin{array}{l}\text { Rest of } \\
\text { UK }\end{array}$ & UK \\
\hline \multicolumn{12}{|l|}{ Table 3.4} \\
\hline Communications Services & * & * & 20 & * & 190 & 155 & 2,165 & 1,420 & 165 & 25 & 4,260 \\
\hline \multicolumn{12}{|l|}{ Table 3.7} \\
\hline Computer and Information & 15 & 95 & 90 & 100 & 75 & 485 & 2,965 & 3,015 & 170 & 250 & 7,260 \\
\hline \multicolumn{12}{|l|}{ Table 3.8} \\
\hline Royalties and Licence Fees (part ${ }^{2}$ ) & 320 & 605 & 80 & 175 & 115 & 370 & 1,340 & 2,765 & 530 & 125 & 6,425 \\
\hline \multicolumn{12}{|l|}{ Table 3.9} \\
\hline \multicolumn{12}{|l|}{ Other business services (part ${ }^{3}$ ) } \\
\hline $\begin{array}{l}\text { Merchanting and other trade } \\
\text { related services }\end{array}$ & 30 & 155 & 50 & 55 & 40 & 100 & 2,000 & 310 & 30 & 120 & 2,890 \\
\hline Legal and accounting & 30 & * & 60 & * & 50 & 95 & 3,835 & 190 & 70 & 115 & 4,865 \\
\hline $\begin{array}{l}\text { Business management \& } \\
\text { consulting }\end{array}$ & 105 & 310 & 175 & 60 & 155 & 470 & 4,210 & 1,270 & 360 & 430 & 7,545 \\
\hline Advertising and Market Research & 5 & 80 & 55 & 10 & 55 & 90 & 2,015 & 250 & 40 & 30 & 2,630 \\
\hline Research and development & 120 & 525 & 175 & 295 & 150 & 1,245 & 435 & 2,200 & 70 & 465 & 5,680 \\
\hline $\begin{array}{l}\text { Architectural, surveying and } \\
\text { construction }^{4}\end{array}$ & * & 80 & 55 & 55 & * & 75 & 375 & 630 & 50 & 350 & 1,770 \\
\hline Engineering \& technical services ${ }^{5}$ & 295 & 405 & 85 & 165 & 85 & 1,095 & 1,325 & 2,060 & 470 & 1,270 & 7,255 \\
\hline $\begin{array}{l}\text { Services between related } \\
\text { enterprises }\end{array}$ & 75 & 145 & 90 & 95 & 85 & 220 & 2,460 & 1,130 & 235 & 320 & 4,855 \\
\hline Services Not Regionalised & & & & & & & & & & & 115,380 \\
\hline Total & & & & & & & & & & & 170,820 \\
\hline
\end{tabular}

Source: BIS analysis of the ONS International Trade in Services (ITIS) survey Notes

1 Figures are not National Statistics and may not be accurate to the level shown. Regional data and UK totals are rounded to the nearest $£ 5$ million and are adjusted to be consistent with Tables 3.1, 3.4, 3.7, 3.8 and 3.9 in the 2010 Pink Book.

2 Excluding Film and television royalties and license fees, see Table 3.8 in the 2010 Pink Book

3 Excluding other miscellaneous business services, see Table 3.9 in the 2010 Pink Book

4 Construction figures from Table 3.1 in the 2010 Pink Book have been combined with figures for Architectural and surveying from Table 3.9

5 Also includes operational leasing and agricultural, mining and on-site processing

* Disclosive data, not available for publication 


\section{Table $4 \quad$ Regional share ${ }^{1}$ of exports of selected services (current prices), 2008}

Percentages

\begin{tabular}{|c|c|c|c|c|c|c|c|c|c|c|c|}
\hline \multirow{2}{*}{ Service } & \multicolumn{11}{|c|}{ Government Office Region (GOR) } \\
\hline & $\begin{array}{l}\text { North } \\
\text { East }\end{array}$ & $\begin{array}{l}\text { North } \\
\text { West }\end{array}$ & $\begin{array}{l}\text { Yorkshire \& } \\
\text { Humber }\end{array}$ & $\begin{array}{c}\text { East } \\
\text { Midlands }\end{array}$ & $\begin{array}{c}\text { West } \\
\text { Midlands }\end{array}$ & Eastern & London & $\begin{array}{l}\text { South } \\
\text { East }\end{array}$ & $\begin{array}{l}\text { South } \\
\text { West }\end{array}$ & $\begin{array}{l}\text { Rest of } \\
\text { UK }\end{array}$ & UK \\
\hline \multicolumn{12}{|l|}{ Table 3.4} \\
\hline Communications Services & * & * & $0 \%$ & * & $5 \%$ & $4 \%$ & $51 \%$ & $33 \%$ & $4 \%$ & $1 \%$ & $100 \%$ \\
\hline \multicolumn{12}{|l|}{ Table 3.7} \\
\hline Computer and Information & $0 \%$ & $1 \%$ & $1 \%$ & $1 \%$ & $1 \%$ & $7 \%$ & $41 \%$ & $42 \%$ & $2 \%$ & $3 \%$ & $100 \%$ \\
\hline \multicolumn{12}{|l|}{ Table 3.8} \\
\hline Royalties and Licence Fees (part ${ }^{2}$ ) & $5 \%$ & $9 \%$ & $1 \%$ & $3 \%$ & $2 \%$ & $6 \%$ & $21 \%$ & $43 \%$ & $8 \%$ & $2 \%$ & $100 \%$ \\
\hline \multicolumn{12}{|l|}{ Table 3.9} \\
\hline \multicolumn{12}{|l|}{ Other business services (part ${ }^{3}$ ) } \\
\hline $\begin{array}{l}\text { Merchanting and other trade } \\
\text { related services }\end{array}$ & $1 \%$ & $5 \%$ & $2 \%$ & $2 \%$ & $1 \%$ & $3 \%$ & $69 \%$ & $11 \%$ & $1 \%$ & $4 \%$ & $100 \%$ \\
\hline Legal and accounting & $1 \%$ & * & $1 \%$ & * & $1 \%$ & $2 \%$ & $79 \%$ & $4 \%$ & $1 \%$ & $2 \%$ & $100 \%$ \\
\hline $\begin{array}{l}\text { Business management \& } \\
\text { consulting }\end{array}$ & $1 \%$ & $4 \%$ & $2 \%$ & $1 \%$ & $2 \%$ & $6 \%$ & $56 \%$ & $17 \%$ & $5 \%$ & $6 \%$ & $100 \%$ \\
\hline Advertising and Market Research & $0 \%$ & $3 \%$ & $2 \%$ & $0 \%$ & $2 \%$ & $3 \%$ & $77 \%$ & $9 \%$ & $2 \%$ & $1 \%$ & $100 \%$ \\
\hline Research and development & $2 \%$ & $9 \%$ & $3 \%$ & $5 \%$ & $3 \%$ & $22 \%$ & $8 \%$ & $39 \%$ & $1 \%$ & $8 \%$ & $100 \%$ \\
\hline $\begin{array}{l}\text { Architectural, surveying and } \\
\text { construction }^{4}\end{array}$ & * & $5 \%$ & $3 \%$ & $3 \%$ & * & $4 \%$ & $21 \%$ & $36 \%$ & $3 \%$ & $20 \%$ & $100 \%$ \\
\hline Engineering \& technical services ${ }^{5}$ & $4 \%$ & $6 \%$ & $1 \%$ & $2 \%$ & $1 \%$ & $15 \%$ & $18 \%$ & $28 \%$ & $6 \%$ & $18 \%$ & $100 \%$ \\
\hline $\begin{array}{l}\text { Services between related } \\
\text { enterprises }\end{array}$ & $1 \%$ & $3 \%$ & $2 \%$ & $2 \%$ & $2 \%$ & $4 \%$ & $51 \%$ & $23 \%$ & $5 \%$ & $7 \%$ & $100 \%$ \\
\hline
\end{tabular}

Source: BIS analysis of the ONS International Trade in Services (ITIS) survey Notes

1 Figures are not National Statistics and may not be accurate to the level shown. Regional data and UK totals are rounded to the nearest $£ 5$ million and are adjusted to be consistent with Tables 3.1, 3.4, 3.7, 3.8 and 3.9 in the 2010 Pink Book.

2 Excluding Film and television royalties and license fees, see Table 3.8 in the 2010 Pink Book

3 Excluding other miscellaneous business services, see Table 3.9 in the 2010 Pink Book

4 Construction figures from Table 3.1 in the 2010 Pink Book have been combined with figures for Architectural and surveying from Table 3.9

5 Also includes operational leasing and agricultural, mining and on-site processing

* Disclosive data, not available for publication 


\section{Map1 Regional share of exports of selected services, 2008}

Percentages of exports of services

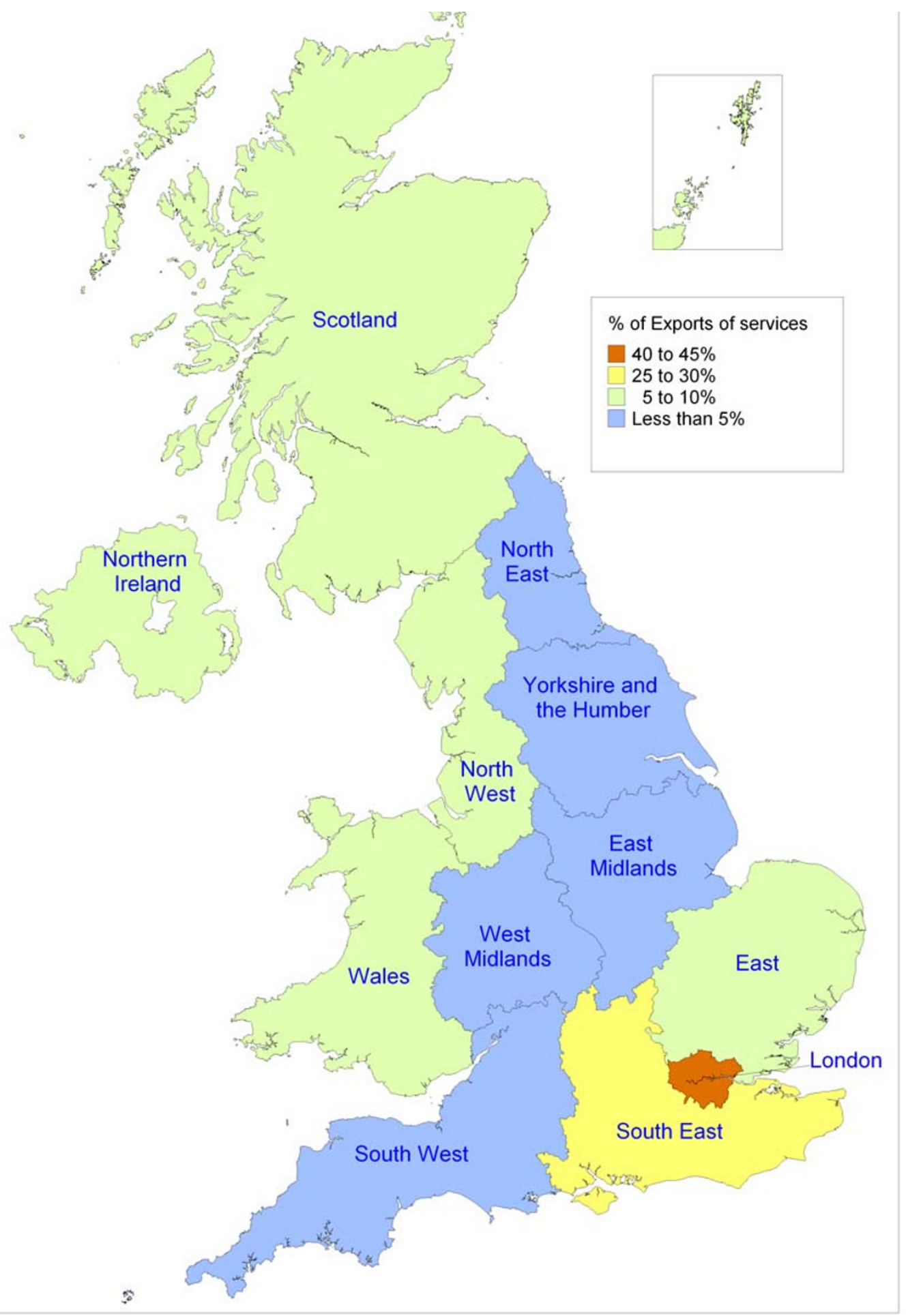

Source: BIS analysis of ONS International Trade in Services (ITIS) Survey

Note: Scotland, Wales and Northern Ireland are combined and treated as a single region 


\section{Figure $6 \quad$ Indexed regionalised exports of services value per economically active adult in 2001 and 2006}

Index, UK $=100$

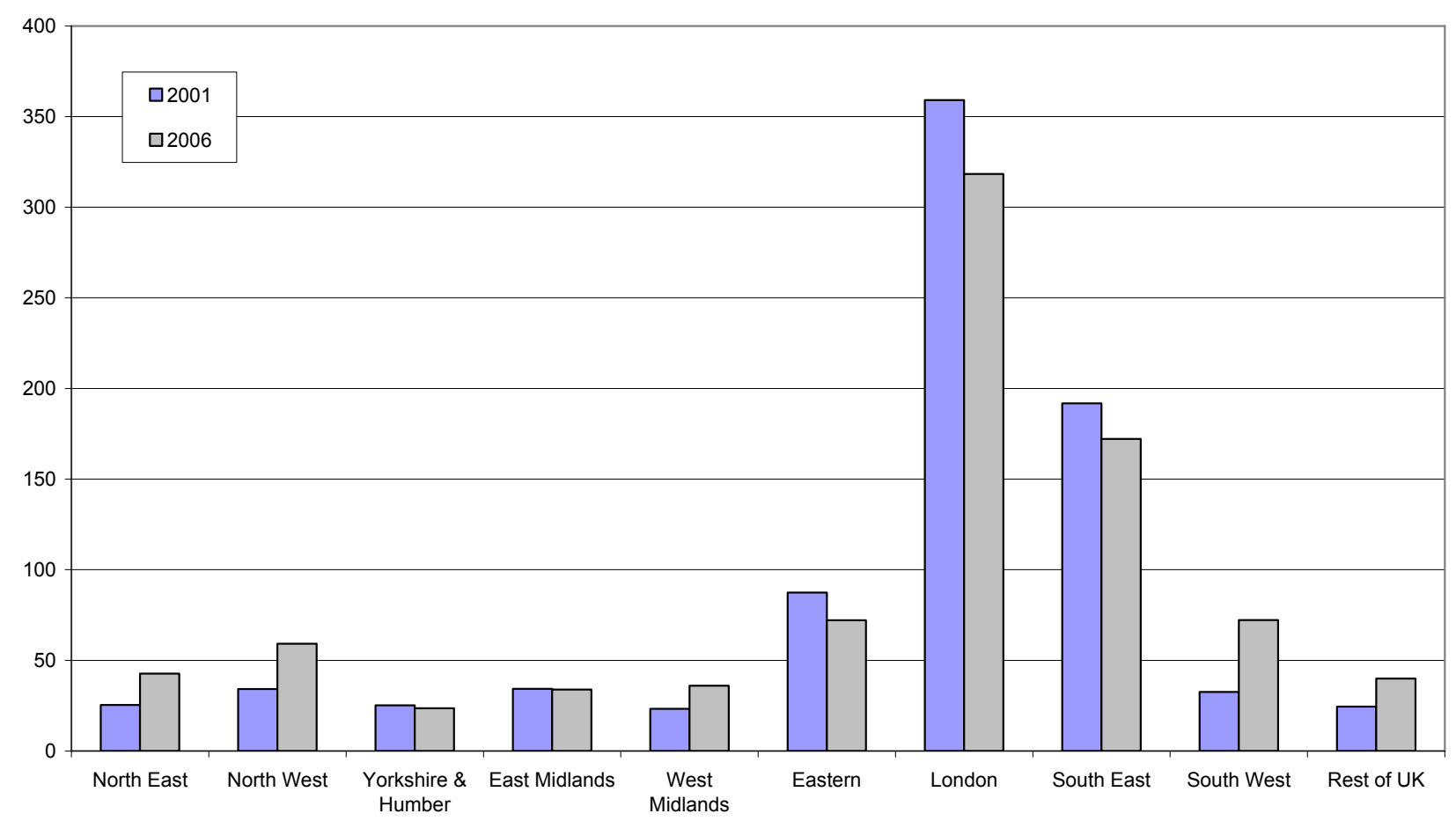

Source: BIS analysis of the ONS International Trade in Services (ITIS) survey

\section{Conclusions}

The Department of Business, Innovation and Skills (BIS) has demonstrated that a regional exports of services analysis can be undertaken by linking company data back into the Inter-Departmental Business Register (IDBR) and apportioning exports to regions using local unit (LU) employment data.

The analysis is mainly limited to Business services and covers about 30 per cent of UK exports of services. Services such as Travel, Transportation, Insurance and Financial services are not available in a format that allows a regional analysis to be undertaken. Allocating some of these services to a region may be less meaningful since the geographic location of the sales transaction and of the service activity may differ.

Apportioning export value to regions by LU employment data is considered to be appropriate where there are a small number of LUs. As the number of LUs in a company increases this is considered to be less valid, since it is unlikely that all of the LUs will be involved in activity 
associated with exports of services. This is particularly so for retail outlets in the Communication and Distribution sectors.

From an analysis of the distribution of the number of LUs in a company and the corresponding number of regions that the LUs have a presence, an allocation method has been adopted that apportions across the LUs where there are less than $10 \mathrm{LUs}$ and allocates to the RU where there are 10 or more LUs. A sensitivity analysis of using an alternative threshold of 5 shows that there is little difference in the regional allocation when using a threshold of 10 or 5 . Results from a one-off 1999 survey of panel members give some support for the validity of the allocation method, although this is based on less than 80 company returns.

Annual variations for a particular product and region may be volatile due to changing patterns in exports of services as individual companies obtain new or end existing contracts. It may also reflect the level of the reliability of the data and analysis method.

It is considered that longer term changes will be less volatile and changes in shares over 5 years, between 2001 to 2006, indicate that the share of exports of services in London and the South East are reducing slightly as other regions increase their share.

\section{Contact}

elmr@ons.gov.uk 